\title{
Interpretation of Kcpx and CaEs in Clinopyroxene from Diamond Inclusions and Mantle Samples
}

Harlow, G.E. ${ }^{1}$

1. Department of Earth \& Planetary Sciences, American Museum of Natural History, New York, NY 10024-5192, U.S.A.

Clinopyroxene ( $\mathrm{Cpx}$ ) has many potential components that make it a monitor of aspects of the growth environment: chemistry, coexisting phases, and conditions. This is particularly important in the upper mantle where high-variance phases like amphibole, mica, and melt or fluid are either rarely or not preserved in samples that reach Earth's surface as xenocrysts, grains in xenoliths, or inclusions in diamonds. Recent multianvil experiments provide some new constraints and insights into environments of clinopyroxenes, particularly with respect to potassium clinopyroxene $\left(\mathrm{KAlSi}_{2} \mathrm{O}_{6}\right.$ or $\left.\mathrm{KCrSi}_{2} \mathrm{O}_{6}-\mathrm{Kcpx}\right)$, calcium-Eskola $\left(\mathrm{Ca}_{0.5} \mathrm{AlSi}_{2} \mathrm{O}_{6}-\mathrm{CaEs}\right)$, and calcium-Tschermaks $\left(\mathrm{CaAlAlSiO}_{6}-\right.$ CaTs) components.

Kcpx: Reports of Kcpx component in clinopyroxenes from the mantle, abundantly reported in the kimberlite/xenolith/diamond literature, have proven (finally) to be real and the result of high pressure (Harlow and Veblen, 1991; Edgar and Vukadinovic, 1995; Harlow, 1997, Luth, 1997), although there is some uncertainty about the extent of solid solution (SS) and partitioning between Cpx and other phases. Synthetic Kcpx content can reach $20 \mathrm{~mol} \%$ (4.2 to $4.7 \mathrm{wt} \% \mathrm{~K}_{2} \mathrm{O}$ ) in both DiKoKcpx and DiJdKcpx intermediate $\left(\mathrm{Di}_{80}-\mathrm{Di}_{40}\right) \mathrm{SSs}$ at $1400-1500^{\circ} \mathrm{C}$ and $10-11 \mathrm{GPa}$ coexisting with a $\mathrm{K}$-rich carbonate or glass or $\mathrm{KAlSi}_{3} \mathrm{O}_{8}$ (Harlow, 1997, and new data). Pressure has a much more important effect than temperature except when Cpx coexists with Opx which leads to increased En content of Cpx at higher T and reduced Kcpx solubility. Larger unit cell volumes and mixing disorder appear to facilitate Kcpx solutions at the same conditions; thus, partitioning can be effected by the Cpx composition, particularly for En-rich or Jd-rich compositions (see Harlow, 1997). Partitioning of K between Cpx and K-carbonate, ${ }^{C p x / c a r b} D_{\mathrm{K}}$, or silicate melt, ${ }^{C p x / m e l t} D_{\mathrm{K}}$, generally ranges from .03 to .07 for P from 5 to $11 \mathrm{GPa}$ and $\mathrm{T}$ from 1400 to $1500^{\circ} \mathrm{C}$ for $\mathrm{Di}-\mathrm{Jd}-\mathrm{K}$-carbonate or $\mathrm{Di}-\mathrm{Ko}-\mathrm{K}$-carbonate (Harlow, 1997), which can be compared to ${ }^{\mathrm{Cpx} / \mathrm{melt}} D_{\mathrm{K}}$, values up to 0.19 (Edgar and Vukadinovic, 1995) for lamproite magma at $1200^{\circ} \mathrm{C}$ and $5 \mathrm{GPa}$ decreasing ten-fold upon increasing $\mathrm{T}$, and from 0.022 at $1400^{\circ} \mathrm{C} @ 5 \mathrm{GPa}$ to 0.11 at $1600^{\circ} \mathrm{C} @ 11 \mathrm{GPa}$ for Di-Phl melting (Luth, 1997).

Experiments have yielded $\mathrm{Cpx}$ with $\mathrm{Kcpx}$ contents far above values reported in natural crystals, so we can infer that these natural samples have not experienced the same combination of high pressure and coexisting high $\mathrm{K}$ activity. Moreover, the Kcpx contents can be used to examine the pressure estimates, suggest coexisting K-rich phases during growth, and judge the experiments.

Vacancies in Cpx-CaEs: Smyth and co-workers have shown the importance of cation vacancies in $\mathrm{Cpx}$, largely attributable to CaEs content, an indicator of high pressure for a $\mathrm{Cpx}+$ silica or anorthite (An) + silica assemblage (Smyth, 1980; McCormick, 1986; Smyth et al. 1991). Gasparik (1986) has measured Di-CaTs-CaEs ternary solutions for starting assemblages of anorthite $+\mathrm{Cpx}$ and anorthite + quartz $+\mathrm{Cpx}$ in the range 1.5 to $3.2 \mathrm{GPa}$ and 1200 to $1450^{\circ} \mathrm{C}$, finding a roughly linear increase $\mathrm{CaEs}$ and $\mathrm{CaTs}$ contents ( 3 to $1: \mathrm{CaTs}$ to $\mathrm{CaEs})$ with pressure for the univariant reaction $\mathrm{Di}+\mathrm{An}=$ garnet $(\mathrm{Gar})+$ kyanite $(\mathrm{Ky})$. Natural examples with such ratios except at near-zero values of $\mathrm{CaEs}$, however, are rare. In experiments reported here, substantial CaEs component in Cpx has been produced in the ternary Di-Jd-Or (actually $\left.\mathrm{Or}_{97} \mathrm{Ab}_{3}\right)$ which is conspicuously sensitive to the breakdown of $\mathrm{KAlSi}_{3} \mathrm{O}_{8}$ feldspar (Or) to $\mathrm{KSi}$-wadeite $\left(\mathrm{K}_{2} \mathrm{Si}_{4} \mathrm{O}_{9}\right)+\mathrm{Ky}+$ coesite with increasing 
pressure $\left(\sim 6 \mathrm{GPa} @ 1000^{\circ} \mathrm{C}\right)$ which then converts to a single hollandite-structure phase $(\sim 9 \mathrm{GPa}$ @ $1000^{\circ} \mathrm{C}$; Yagi et al., 1994). A sampling of results follows:

\begin{tabular}{|c|c|c|c|c|c|c|c|c|c|}
\hline Exper. & Contents & $\mathrm{P}(\mathrm{GPa})$ & $\mathrm{T}\left({ }^{\circ} \mathrm{C}\right)$ & Phases + Cpx & $\mathrm{Di}$ & $\mathrm{Jd}$ & $\mathrm{Kcpx}$ & CaTs & $\mathrm{CaEs}$ \\
\hline GG566 & $\mathrm{Di}+\mathrm{Or}$ & 6 & 1400 & Glass & 76 & 10 & 1 & 5 & 0 \\
\hline GG566 & $\mathrm{Di}+\mathrm{Or}$ & 6 & 1400 & Glass & 69 & 18 & 1 & 5 & 0 \\
\hline GG535 & $\mathrm{Di}+\mathrm{Or}$ & 8.5 & 1500 & Ky, Glass & 28 & 37 & 5 & 8 & 14 \\
\hline GG535 & $\mathrm{Di}+\mathrm{Or}$ & 8.5 & 1500 & Ky, Glass & 49 & 24 & 7 & 5 & 8 \\
\hline GG606 & $\mathrm{Di}+\mathrm{Or}$ & 9 & 1500 & Gar, Ky, Glass & 42 & 23 & 5 & 8 & 16 \\
\hline GG606 & $\mathrm{Di}+\mathrm{Or}$ & 9 & 1500 & Gar, Ky, Glass & 50 & 16 & 3 & 10 & 12 \\
\hline BB367 & $\mathrm{Di}+\mathrm{Or}$ & 9.5 & 1500 & Ky, K-Wad, Sil & 39 & 25 & 19 & 4 & 10 \\
\hline BB367 & $\mathrm{Di}+\mathrm{Or}$ & 9.5 & 1500 & Ky, K-Wad, Sil & 37 & 25 & 11 & 4 & 14 \\
\hline BB367 & $\mathrm{Di}+\mathrm{Or}$ & 9.5 & 1500 & Ky, K-Wad, Sil & 25 & 39 & 18 & 4 & 10 \\
\hline GG544 & $\mathrm{Di}_{50} \mathrm{Jd}_{50}+\mathrm{Or}$ & 10 & 1500 & Ky, K-Wad?, Sil & 21 & 52 & 8 & 1 & 13 \\
\hline GG544 & $\mathrm{Di}_{50} \mathrm{Jd}_{50}+\mathrm{Or}$ & 10 & 1500 & Ky, K-Wad?, Sil & 57 & 30 & 7 & 0 & 4 \\
\hline GG544 & $\mathrm{Di}_{50} \mathrm{Jd}_{50}+\mathrm{Or}$ & 10 & 1500 & Ky, K-Wad?, Sil & 73 & 15 & 10 & 1 & 0 \\
\hline TT155 & $\mathrm{Di}+\mathrm{Or}$ & 11 & 1400 & K-Hollandite & 73 & 10 & 15 & 0 & 2 \\
\hline TT155 & $\mathrm{Di}+\mathrm{Or}$ & 11 & 1400 & K-Hollandite & 56 & 25 & 17 & 0 & 1 \\
\hline
\end{tabular}

Pressure favors both CaEs and Kcpx content in the assemblages, but the presence of both an aluminous phase and silica, rather than just bulk composition, is very important to CaEs enrichment and perhaps somewhat to CaTs content. CaTs, a high-T component, drops upon rising P. These data do not clearly show partitioning w.r.t. $\mathrm{K}\left(28 \mathrm{wt} \% \mathrm{~K}_{2} \mathrm{O}\right.$ in $\mathrm{K}-\mathrm{Wad}$ and $16 \mathrm{wt} \%$ in Or).

Cpx in diamonds: A characteristic typical of some Cpx inclusions in diamonds is their measurable $\mathrm{K}$ content, as well as for Cpx in Group I and diamondiferous eclogites (McCandless and Gurney, 1989). A cursory examination shows that omphacite inclusions from Sloan, Monastery, Orapa, Argyle, and Copetown have a high-end range of 0.6 to 0.9 wt $\% \mathrm{~K}_{2} \mathrm{O}$ with $\leq \mathrm{CaEs}_{2}$, suggesting coexistence with a melt/fluid of 1.2 to $30 \mathrm{wt} \% \mathrm{~K}_{2} \mathrm{O}$ without coexisting $\mathrm{Ky}$ (or corundum?); this author would lean toward more K-rich melt/fluids. Some omphacite inclusions from Arkangelsk (Sobolev et al., 1997) contain both significant CaEs component, up to 9\%, and $\mathrm{Kcpx}$, to 8\%, suggesting both a K-rich fluid/solid phase and something like Ky coexisted. Few ultramafic Crdiopsides are K-rich, and the richest are from the Koffiefontein pipe (Rickard et al., 1989) with 0.6 and $1.6 \mathrm{wt} \% \mathrm{~K}_{2} \mathrm{O}$ suggesting perhaps both high pressure, $>5 \mathrm{GPa}$, and $\mathrm{K}$-rich coexisting phase, $>25$ wt $\% \mathrm{~K}_{2} \mathrm{O}$, both unusual.

Cpx coexisting with phlogopite: Data from Luth (1997) yield a ${ }^{\mathrm{Cpx} / \mathrm{Phl}} D_{\mathrm{K}}$ of 0.013 to 0.08 from 1250

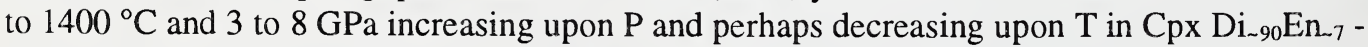
$\mathrm{CaTs}_{1-4} \mathrm{Kcpx}_{1-4} \mathrm{CaEs}_{0}$. That is comparable to this author's experiments with natural phases that yield $\mathrm{Cpx}$ of $\mathrm{Di}_{83-75} \mathrm{Jd}_{5-10} \mathrm{En}_{-7} \mathrm{CaTs}_{1-2} \mathrm{Kcpx}_{1-3} \mathrm{CaEs}_{0}$, however, addition of K-bicarbonate maintains Phl to $1500{ }^{\circ} \mathrm{C}$ and $10 \mathrm{GPa}$ with apparent ${ }^{\mathrm{Cpx} / \mathrm{Phl}} D_{\mathrm{K}}$ of 0.07 to 0.09 and $\mathrm{Cpx} \mathrm{Di}_{77-70} \mathrm{En}_{23-26} \mathrm{Jd}_{1} \mathrm{CaTs} s_{1}$ -

$\mathrm{Kcpx}_{3-4} \mathrm{CaEs}_{0}$. Data from the literature on xenoliths with 0.01 to $0.07 \mathrm{wt} \% \mathrm{~K}_{2} \mathrm{O}$ in diopsidic $\mathrm{Cpx}$ coexisting with $\mathrm{Phl}$ (e.g., Carswell, 1989) are not consistent with coexistence at mantle conditions, whereas the inclusions of $\mathrm{Phl}$ and $\mathrm{Cpx}\left(0.48 \mathrm{wt} \% \mathrm{~K}_{2} \mathrm{O}\right)$ in the F70 diamond from the Finsch pipe of Gurney et al. (1979) are consistent with an equilibrium pair at about $1200{ }^{\circ} \mathrm{C}$ and $5 \mathrm{GPa}$.

Cpx in kyanite eclogite: Many of the Cpx analyses with cation deficiencies are from Ky or corundum eclogites or grospydites (e.g., Smyth, 1980; Smyth et al., 1991) and many have 0.05 to 0.2 wt\% $\mathrm{K}_{2} \mathrm{O}$ (e.g., $\mathrm{Di}_{36} \mathrm{Jd}_{45} \mathrm{CaEs}_{10} \mathrm{CaTs}_{5} \mathrm{En}_{3} \mathrm{Kcpx}_{1}$ ). Using the range of partition coefficients above, $\mathrm{K}$-content in Cpx would suggest, a coexisting phase with up to $10 \mathrm{wt} \% \mathrm{~K}_{2} \mathrm{O}$; CaEs/CaTs above unity suggests 
other than anorthite breakdown as the control. From the experimental results above, a phase more like K-feldspar, perhaps phengite or Phl $\left(\sim 10 \mathrm{wt} . \% \mathrm{~K}_{2} \mathrm{O}\right)$, could be the missing phase (fictive or real) to yield $\mathrm{K}$-rich $\mathrm{Cpx}$ in these rocks.

\section{References}

Carswell, D.A. (1989) Primary and secondary phlogopites and clinopyroxenes in garnet lherzolite xenoliths, in J. Ross et al. eds., Kimberlites and Related Rocks, vol. 2: Their Mantle/Crust Setting, Diamonds and Diamond Exploration: Victoria, Australia, Geol. Soc. of Australia Special Publication 14, Blackwell Scientific Publications, p. 417-429.

Edgar, A.D., and Vukadinovic, D., 1993, Potassium-rich clinopyroxene in the mantle: An experimental investigation of a K-rich lamproite up to $60 \mathrm{kbar}$ : Geochim. et Cosmochim. Acta, 57, p. 5063-5072.

Gasparik, T.,1986, Experimental study of subsolidus phase relations and mixing properties of clinopyroxene in the silica-saturated system $\mathrm{CaO}-\mathrm{MgO}-\mathrm{Al}_{2} \mathrm{O}_{3}-\mathrm{SiO}_{2}$ : Amer. Mineral., 71, p. 686-694. Gurney, J.J., Harris, J.W., and Rickard, R.S., 1979, Silicate and oxide inclusions in diamonds from the Finsch kimberlite pipe, in Boyd, F.R. and Meyer, H.O.A., eds., Kimberlites, diatremes and diamonds: their geology, petrology, and geochemistry: Washington, Amer. Geophys. Union, p. 1-15. Harlow, G.E., 1997, K in clinopyroxene at high pressure and temperature: An experimental study:

Amer. Mineral., 82, p. 259-269.

Harlow, G.E., and Veblen, D. R., 1991, Potassium in clinopyroxene inclusions from diamonds: Science, 251, p. 652-655.

Luth, R.W., 1997, Experimental study of the system phlogopite-diopside from 3.5 to $17 \mathrm{GPa}$ : Amer.

Mineral., 82, p. 1198-1209.

McCandless, T.E., and Collins, D.S., 1989, A diamond-graphite eclogite from the Sloan 2 kimberlite, Colorado, U.S.A., in J. Ross et al. eds., Kimberlites and Related Rocks, vol. 2: Their Mantle/Crust Setting, Diamonds and Diamond Exploration: Victoria, Australia, Geol. Soc. of Australia Special Publication 14, Blackwell Scientific Publications, p. 1063-1069.

McCandless, T.E., and Gurney, J.J., 1989, Sodium in garnet and potassium in clinopyroxene: criteria for classifying mantle eclogites, in J. Ross et al. eds., Kimberlites and Related Rocks, vol. 2: Their Mantle/Crust Setting, Diamonds and Diamond Exploration: Victoria, Australia, Geol. Soc. of Australia Special Publication 14, Blackwell Scientific Publications, p. 827-832.

McCormick, T.C. (1986) Crystal-chemical aspects of nonstoichiometric pyroxenes: Amer. Mineral., 71, p. 1434-1440.

Rickard, R.S., Harris, J.W., Gurney, J.J., \& Cardoso, P., 1989, Mineral inclusions in diamonds from the Koffiefontein Mine, in J. Ross et al. eds., Kimberlites and Related Rocks, vol. 2: Their Mantle/Crust Setting, Diamonds and Diamond Exploration: Victoria, Australia, Geol. Soc. of Australia Special Publication 14, Blackwell Scientific Publications, 1054-1062

Smyth, J.R.,1980, Cation vacancies and the crystal chemistry of breakdown reactions in kimberlitic omphacites: Amer. Mineral., 65, p. 1185-1264.

Smyth, J.R., McCormick, T.C., and Caporuscio, F.A., 1991, Pyroxene crystal chemistry and the evolution of eclogites in the mantle, in Fifth International Kimberlite Conference; extended abstracts: Brasília, CPRM Special Publication 2/91, p. 385-387.

Sobolev, N. V., Yefimova, E. S., Reimers, L.F., Zakharchenko, O.D., Makhin, A.I., and Usova, L.V., 1997, Mineral inclusions in diamonds of the Arkangelsk kimberlite province, in Proceedings of the Sixth International Kimberlite Conference, Vol. 2: Diamonds: Characterization, Genesis and Exploration: Russian Geology and Geophysics, 38, p. 379-393.

Yagi, A., Suzuki, T. and Akaogi, M., 1994, High pressure transition in the system $\mathrm{KAlSi}_{3} \mathrm{O}_{8}-$ $\mathrm{NaAlSi}_{3} \mathrm{O}_{8}$ : Phys. Chem. Minerals, 21, p. 12-17. 